\title{
Raxibacumab: potential role in the treatment of inhalational anthrax
}

This article was published in the following Dove Press journal:

Infection and Drug Resistance

29 April 2014

Number of times this article has been viewed

\section{Carlos E Kummerfeldt \\ Division of Pulmonary, Critical Care, Allergy and Sleep Medicine, Medical University of South \\ Carolina, Charleston, SC, USA}

\section{Video abstract}

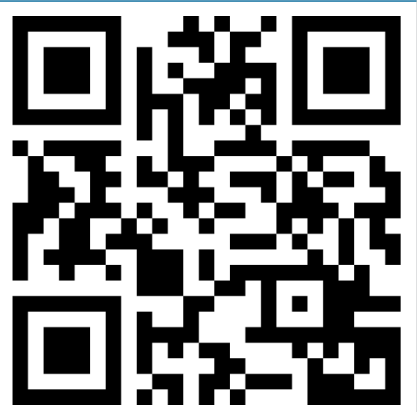

Point your SmartPhone at the code above. If you have a QR code reader the video abstract will appear. Or use: http://dvpr.es/IrmzddX
Correspondence: Carlos E Kummerfeldt Division of Pulmonary, Critical Care, Allergy and Sleep Medicine, Medical University of South Carolina, 96 Jonathan Lucas St, Suite 812-CSBMSC

630, Charleston, SC 29425-6300, USA

Email kummerfe@musc.edu
Abstract: Anthrax is a highly contagious and potentially fatal human disease caused by Bacillus anthracis, an aerobic, Gram-positive, spore-forming rod-shaped bacterium with worldwide distribution as a zoonotic infection in herbivore animals. Bioterrorist attacks with inhalational anthrax have prompted the development of more effective treatments. Antibodies against anthrax toxin have been shown to decrease mortality in animal studies. Raxibacumab is a recombinant human monoclonal antibody developed against inhalational anthrax. The drug received approval after human studies showed its safety and animal studies demonstrated its efficacy for treatment as well as prophylaxis against inhalational anthrax. It works by preventing binding of the protective antigen component of the anthrax toxin to its receptors in host cells, thereby blocking the toxin's deleterious effects. Recently updated therapy guidelines for Bacillus anthracis recommend the use of antitoxin treatment. Raxibacumab is the first monoclonal antitoxin antibody made available that can be used with the antibiotics recommended for treatment of the disease. When exposure is suspected, raxibacumab should be given with anthrax vaccination to augment immunity. Raxibacumab provides additional protection against inhalational anthrax via a mechanism different from that of either antibiotics or active immunization. In combination with currently available and recommended therapies, raxibacumab should reduce the morbidity and mortality of inhalational anthrax.

Keywords: anthrax, monoclonal antibody, protective antigen, raxibacumab

\section{Introduction}

In December 2012, the United States Food and Drug Administration (FDA) approved raxibacumab for treatment of and prophylaxis against inhalational anthrax. ${ }^{1}$ Its labeled uses are to treat inhalational anthrax in combination with appropriate antibacterial drugs, and for prophylaxis when alternative therapies are not appropriate or available. ${ }^{2}$ For its approval, the FDA granted fast track designation, priority review, orphan product designation, and applied the Animal Efficacy Rule. Under this rule, medications are given FDA approval based on efficacy findings from adequate and well controlled animal studies when it is not feasible or ethical to conduct studies in human subjects. ${ }^{3}$ Inhalational anthrax is a rare and lethal disease, so efficacy studies are unethical and prohibited in humans.

After the bioterrorist attacks of September 2001, which resulted in eleven confirmed cases of inhalational anthrax and five fatalities, the US government enacted new rules and regulations to encourage pharmaceutical industry development of medical countermeasures against bioterrorist threats. ${ }^{4,5}$ The Project Bioshield Act was signed into law on July 2004 and provided funding for the development of raxibacumab. 
Under Project Bioshield, the pharmaceutical company, Human Genome Sciences (GlaxoSmithKline, Research Triangle Park, NC, USA) was awarded a contract to develop and deliver human immune globulin against anthrax. ${ }^{5}$ The reason for commissioning the development of passive immunity is that current recommendations for therapy and exposure prophylaxis have limitations. ${ }^{6,7}$

\section{Why is raxibacumab needed?}

Current therapy guidelines recommend use of antibiotics that are highly effective against Bacillus anthracis, but until recently did not recommend administration of antitoxin therapy. Patients die due to toxin-induced disease despite effective antibiotic use that kills the bacteria. ${ }^{8}$ Toxin levels are highest during initial presentation and decline with early antibiotic administration. ${ }^{9}$ The Anthrax Vaccine Adsorbed (BioThrax ${ }^{\circledR}$; Emergent BioSolutions Inc., Rockville, MD, USA) licensed for use in the USA requires at least 4 weeks to develop sufficient protective immunity. ${ }^{7}$ Exposed patients are at risk of disease despite receiving immunization, given the bacteria's short incubation period of at least 4 days after inhalation. Another concern is adherence with the recommended 2-month oral antibiotic regimens against exposure prophylaxis. In a study of antibiotic adherence among postal workers in Washington after the terrorist attacks of 2001 , only $40 \%$ of those sampled reported full adherence, while another $18 \%$ had completely discontinued their prophylaxis. ${ }^{10}$ The US Centers for Disease Control and Prevention recently updated their guidelines in 2014 and support the use of antitoxin therapy (either raxibacumab or anthrax immune globulin) in combination with antimicrobial drug treatment in any patient for whom there is a high level of clinical suspicion for inhalational anthrax. They acknowledge that optimal timing of antitoxin administration remains unknown given the lack of data. ${ }^{11}$

Thus, passive immunity in the form of protective antibodies has a role in treatment as well as post-exposure prophylaxis against inhalational anthrax. This review discusses raxibacumab (Abthrax ${ }^{\circledR}$, GlaxoSmithKline), the first human monoclonal antibody approved for treatment and prophylaxis against inhalational anthrax.

\section{Pathophysiology of anthrax}

B. anthracis is a large rod-shaped, aerobic, Gram-positive, spore-forming bacterium that exists in a spore or vegetative state. The spore is the dormant form and is found in soils around the world. Anthrax spores are stable particles that can withstand very extreme conditions due to their highly coated and thick protein shell. This allows spores to survive in an adverse environment for prolonged periods of time. ${ }^{12}$
The vegetative state is the replicating form that exists during active infection. Herbivore mammals typically acquire the infection after ingestion of spores, with transmission to humans upon contact with contaminated animal products.

Infection in humans results in four recognized forms of the disease, depending on the route of entry, ie, cutaneous, gastrointestinal, injection, and inhalational anthrax..$^{13,14}$ Cutaneous anthrax is the most common and frequently resolves spontaneously. Initially, a painless or pruritic papule appears, and is surrounded by edema. The papule progresses to a vesicle, rupturing and creating an ulcer covered by a black eschar that sloughs 2-3 weeks later. Gastrointestinal anthrax occurs after ingestion of contaminated meat. Spores germinate, resulting in oropharyngeal and gastrointestinal ulceration, followed by regional lymphadenopathy, edema, sepsis, necrosis, and perforation. Ascites can also occur. Patients develop nausea, vomiting, bloody diarrhea, and ultimately pain resulting in an acute abdomen. Intravenous or intramuscular drug use results in injectional anthrax where the typical black eschar is absent. Patients develop subcutaneous lesions that lead to sepsis. Inhalational anthrax occurs after inhaled spores are phagocytosed by alveolar macrophages that carry the spores to hilar and mediastinal lymph nodes where they germinate. Germination results in hemorrhagic mediastinitis, bilateral hemorrhagic pleural effusions, dyspnea, hypotension, shock, and death. Patients initially present with influenza-like symptoms during the first 4 days, but rapidly progress to respiratory failure. ${ }^{13,14}$

The anthrax genome is comprised of a single covalently closed chromosome. It contains two virulent plasmids, pXO1 and $\mathrm{pXO} 2$, responsible for synthesizing the immunologically inert capsule and the anthrax toxin, respectively. ${ }^{15}$ The capsule is composed of poly- $\gamma$-D-glutamyl amino acids and protects the bacteria from phagocytosis. ${ }^{16,17}$ The anthrax toxin is composed of two binary combinations, each containing a common binding component known as protective antigen (PA). The other two components, edema factor and lethal factor, are enzymes. PA combines with edema factor to form edema toxin, and in a similar way with lethal factor to form lethal toxin. PA is a protein that mediates binding to its receptors in the cell membrane of host cells. Binding to either a high-affinity or low-affinity receptor (ANTXR1/2) that may or may not require a coreceptor (LRP6) occurs, with subsequent transformation of PA, resulting in pore formation and facilitating translocation of edema factor and lethal factor into the cell cytosol (Figure 1). ${ }^{18,19} \mathrm{PA}$ is therefore essential for intracellular translocation of both edema and lethal toxins. PA induces immunization, and all current acellular or attenuated live anthrax vaccines contain or express PA. ${ }^{20}$ 


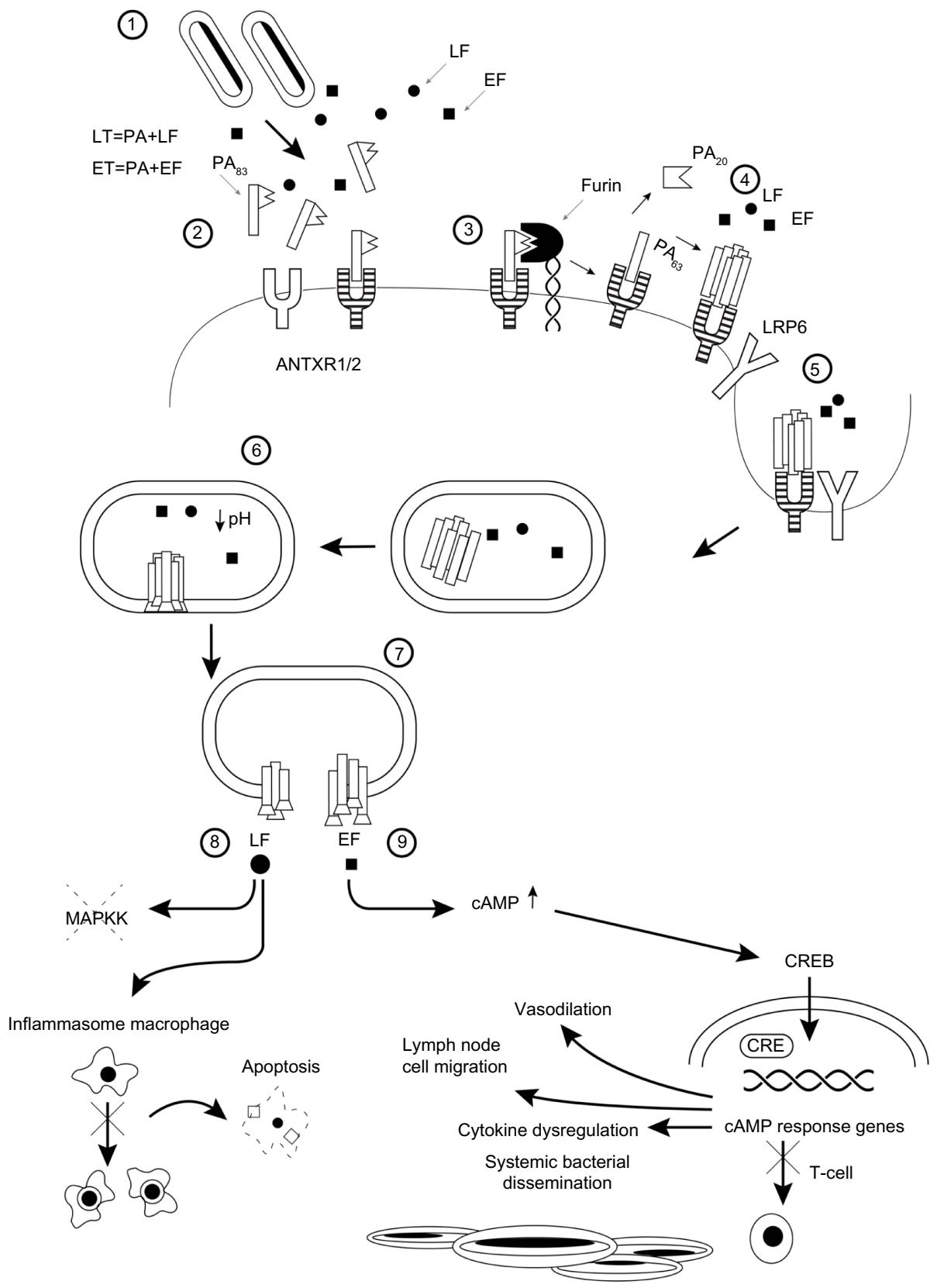

Figure I Pathophysiology of anthrax illustrated as a series of steps. I) Bacillus anthracis spores germinate and release lethal factor and PA. Initially, PA is an $83 \mathrm{kDa}$ monomer. 2) $\mathrm{PA}_{83}$ binds to the ANTXRI/2 transmembrane receptors in the host cell. 3) Furin, a cell surface proprotein convertase, cleaves $\mathrm{PA}_{83}$ into $\mathrm{PA}_{20}$ and $\mathrm{PA}_{63}$ fragments. The $\mathrm{PA}_{20}$ fragment is cleaved off while $\mathrm{PA}_{63}$ remains bound to the receptor. 4) Proteolytically processed $\mathrm{PA}_{63}$ monomers assemble into a heptameric or octameric $\mathrm{PA}$ prepore. The PA prepore can bind up to three or four lethal factor or monomers. 5) Prepore clusters are internalized with or without the LRP6 coreceptor via receptor-mediated endocytosis, resulting in endosome formation. 6) Acidification of endosome results in prepore transformation into a transmembrane delivery pore. 7) Release of lethal factor and edema factor inside the cell. 8) Lethal factor, a zinc metalloproteinase, inactivates MAPKK, resulting in impaired lymphocyte activation, B cell proliferation, as well as macrophage apoptosis via activation of the cytosolic inflammasome pathway. 9) A calcium-dependent and calmodulin-dependent adenylate cyclase increases intracellular cAMP, resulting in activation of CAMP response genes. Migration of infected macrophages to lymph nodes is stimulated, as well as inhibition of $T$ cell activation, impaired phagocytosis, oxidative burst, and cytokine dysregulation. cAMP induces vasodilation, leading to edema.

Abbreviations: LF, lethal factor; EF, edema factor; PA, protective antigen; LT, lethal toxin; ET, edema toxin; ANTXRI/2, low (ANTXRI, previously tumor endothelial marker) or high (ANTXR2, previously capillary morphogenesis protein) type I transmembrane receptors; LRP6, low-density lipoprotein receptor-related protein 6; MAPKK, mitogen-activated protein kinase kinases; CREB, CAMP response element binding protein; CRE, cAMP-response elements; cAMP, cyclic adenosine monophosphate.

Edema factor is a calcium-dependent and calmodulindependent adenylate cyclase that increases intracellular levels of cyclic adenosine monophosphate. ${ }^{21}$ Edema toxin results in cell and tissue edema. Patients develop pulmonary edema, congestion, and large serosanguinous exudative pleural effusions. ${ }^{22,23}$ Lethal factor is a zinc metalloproteinase that inactivates mitogen-activated protein kinase-kinase. Lethal toxin impairs both innate and adaptive immune reactions, leading to uncontrolled bacterial proliferation and cell death. ${ }^{24,25}$ Patients develop 
hemorrhagic mediastinitis from lymph node ulceration and septic shock. ${ }^{26}$

Efforts directed at preventing anthrax toxin from entering the cell should avoid the deleterious effects of edema and lethal toxins. The most effective way to neutralize these toxins is to inhibit their common binding component, PA. Inhibition of PA would prevent its binding to the cell membrane and translocation of the toxin into the cell.

\section{Mechanism of action}

Raxibacumab is a recombinant human immunoglobulin G1 $\lambda$ monoclonal antibody that blocks the binding of PA to its cell receptor, thereby inhibiting pore formation and internalization of edema and lethal toxins (Figure 2). 2,27,28 The antibody was derived from a phage display library licensed by Human Genome Sciences from Cambridge Antibody Technology (AstraZeneca, London, UK). Raxibacumab binds to PA at the domain IV epitope with an affinity of $2.78 \pm 0.9 \mathrm{nM}$, and its inhibition is dose-dependent. ${ }^{29,30}$ Raxibacumab does not have any direct antibacterial activity. Therefore, it is advised that its use should be combined with the antibiotics recommended for the treatment of anthrax.

\section{Pharmacokinetics}

Raxibacumab shows linear pharmacokinetics over a dose range of $1-40 \mathrm{mg} / \mathrm{kg}$ after administration of a single intravenous dose. Serum levels can be detected for up to 56 days

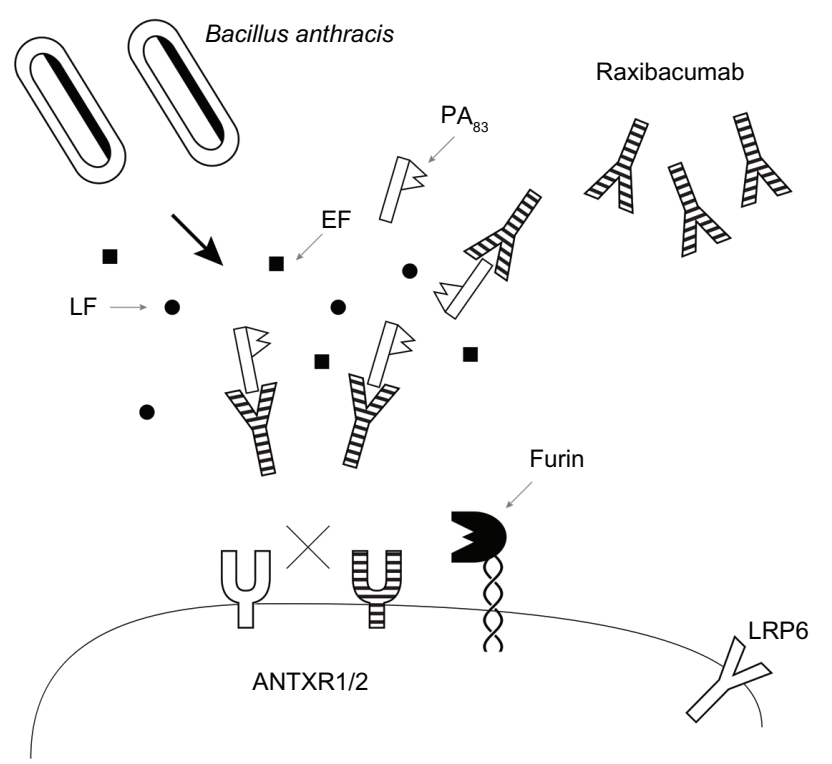

Figure 2 Raxibacumab inhibits binding of PA to the ANTXRI/2 transmembrane receptors in the host cell.

Abbreviations: LF, lethal factor; EF, edema factor; PA, protective antigen; ANTXRI/2, low (ANTXRI, previously tumor endothelial marker) or high (ANTXR2, previously capillary morphogenesis protein) type I transmembrane receptors; LRP6, low-density lipoprotein receptor-related protein 6. after administration. Raxibacumab has a mean half-life of 16-19 days, and has limited renal clearance. Its steady-state volume ranges from $58 \mathrm{~mL} / \mathrm{kg}$ to $73 \mathrm{~mL} / \mathrm{kg}$, suggesting tissue distribution. ${ }^{31}$ Raxibacumab does not penetrate the blood-brain barrier. ${ }^{2}$ When given with intravenous or oral ciprofloxacin, serum concentrations of neither medication are affected and the regimen is well tolerated. ${ }^{27}$

\section{Dosage, administration, and safety}

In adults, raxibacumab is given as a single intravenous dose of $40 \mathrm{mg} / \mathrm{kg}$ over 2 hours and 15 minutes. The medication is diluted in $0.9 \%$ normal saline to give a total volume of $250 \mathrm{~mL}$, and $25 \mathrm{mg}$ or $50 \mathrm{mg}$ of oral or intravenous diphenhydramine should be given within one hour to reduce the risk of infusion reactions. ${ }^{2}$ The intravenous route is perceived as disadvantageous given that the intramuscular and subcutaneous routes are easier ways to administer the drug. A Phase I study showed that two intramuscular injection sites produced different bioavailabilities when compared with intravenous infusion. ${ }^{31}$ All studies evaluating the safety of raxibacumab have been done in adults (Table 1). 27,29,31 The most common reactions reported during infusion included rash, urticaria, and pruritus. Other reactions included headache, upper respiratory tract infection, nausea, pain in arm or leg, cough, and arthralgias. ${ }^{27}$ The following adverse reactions were seen more commonly with raxibacumab than placebo but occurred in less than $1.5 \%$ of subjects given raxibacumab: lymphadenopathy, palpitations, vertigo, fatigue, infusion site pain, peripheral edema, back pain, muscle spasms, vasovagal syncope, insomnia, flushing, and hypertension. Laboratory abnormalities seen after drug infusion included anemia, leukopenia, elevated amylase and creatine phosphokinase, and prolonged prothrombin time. ${ }^{2}$ All adverse events resolved within the time period that safety studies were conducted. ${ }^{27}$ Raxibacumab is considered a pregnancy category B medication (ie, no evidence of risk in animal studies, but no adequate human studies in pregnancy available).,28

\section{Safety studies}

Four substudies were performed by Human Genome Sciences to assess the safety, tolerability, and pharmacokinetics of raxibacumab in healthy humans (Table 1). The first was a randomized, single-blind, placebo-controlled Phase I dose-escalation study conducted in 105 healthy volunteers. ${ }^{31}$ Subjects received placebo or raxibacumab as a single intramuscular injection or intravenous infusion. Three intramuscular and five intravenous dose levels were studied, along with two intramuscular injection sites. The 
Table I Human substudies on raxibacumab

\begin{tabular}{|c|c|c|c|c|}
\hline Study & Objective & Endpoint & Design & Results \\
\hline $\begin{array}{l}\text { Subramanian } \\
\text { et } \mathrm{al}^{|3|}\end{array}$ & Safety & $\begin{array}{l}\text { Pharmacokinetics, safety, and } \\
\text { biological activity }\end{array}$ & $\begin{array}{l}\text { I05 subjects ( } 80 \text { raxibacumab, } 25 \text { placebo) } \\
\text { IM (vastus lateralis or gluteus maximus) } \\
\text { injection }(0.3, \mathrm{I} \text {, or } 3 \mathrm{mg} / \mathrm{kg}) \text { or placebo; } \\
\text { IV injection }(\mathrm{I}, 3, \mathrm{I}, 20 \text {, or } 40 \mathrm{mg} / \mathrm{kg}) \text { or } \\
\text { placebo }\end{array}$ & $\begin{array}{l}\text { Half-life I5-19 days for IM and } \\
\text { 16-19 days for IV injection; linear } \\
\text { pharmacokinetics with both } \\
\text { routes of administration. Higher } \\
\text { bioavailability in IM vastus lateralis } \\
\text { than gluteus maximus }\end{array}$ \\
\hline Migone et $\mathrm{al}^{27}$ & Safety & $\begin{array}{l}\text { Safety and pharmacokinetics } \\
\text { of concomitant administration } \\
\text { with ciprofloxacin }\end{array}$ & $\begin{array}{l}88 \text { subjects divided in three groups: } \\
\text { raxibacumab plus ciprofloxacin (ciprofloxacin } \\
500 \mathrm{mg} \text { orally every } 12 \text { hours for } 6 \text { days, } \\
\text { then a single dose of raxibacumab on day } 5 \text { ); } \\
\text { raxibacumab only (single dose on day } 0 \text { ), or } \\
\text { ciprofloxacin only ( } 400 \mathrm{mg} \text { IV every } 12 \text { hours } \\
\text { on day } 0 \text {, then } 500 \mathrm{mg} \text { orally every } 12 \text { hours } \\
\text { for } 6 \text { days) }\end{array}$ & $\begin{array}{l}\text { No alterations in pharmacokinetics } \\
\text { of raxibacumab or ciprofloxacin; } \\
\text { safe to give both together }\end{array}$ \\
\hline Migone et $\mathrm{al}^{27}$ & Safety & $\begin{array}{l}\text { l4-day safety of additional dose } \\
\text { and maintenance of drug serum } \\
\text { levels }\end{array}$ & $\begin{array}{l}320 \text { subjects ( } 291 \text { assigned to a single dose } \\
\text { versus placebo; } 29 \text { assigned to a double dose } \\
\text { at day } 0 \text { and day } 14 \text { versus placebo) }\end{array}$ & $\begin{array}{l}\text { No significant difference in adverse } \\
\text { reactions; no difference in serum } \\
\text { levels of drug maintained at } 28 \text { days }\end{array}$ \\
\hline Migone et $\mathrm{al}^{27}$ & Safety & $\begin{array}{l}\text { Four-month safety of additional } \\
\text { booster dose }\end{array}$ & $\begin{array}{l}20 \text { subjects who had already received } \\
\text { raxibacumab given repeat "booster" at } \\
4 \text { months }\end{array}$ & Not published \\
\hline
\end{tabular}

Abbreviations: IM, intramuscular; IV, intravenous.

pharmacokinetics, half-life, and different bioavailabilities were calculated. This study showed that raxibacumab was safe, well tolerated, and bioavailable after a single intravenous or intramuscular dose. The second study was an open-label Phase I evaluation of the pharmacokinetics and safety of intravenous raxibacumab given at a dose of 40 $\mathrm{mg} / \mathrm{kg}$ in combination with ciprofloxacin. ${ }^{27}$ Concomitant use of ciprofloxacin did not reduce the serum concentrations of either drug. The third study was a randomized, placebocontrolled comparison of a single dose of raxibacumab versus two doses of the drug. ${ }^{27}$ The results of this study were combined with those of the previous two studies and did not find significant differences in adverse reactions when compared with placebo. The fourth study was an open-label evaluation of the persistence of immunogenicity and safety with a repeat dose of intravenous raxibacumab at 4 months. ${ }^{27}$ The results of this last study have not yet been published. It is unethical and illegal to perform prophylactic and therapeutic efficacy studies in humans, so the majority of these studies have been performed in animals.

\section{Animal studies}

Prophylactic and therapeutic efficacy studies were conducted in rats, rabbits, and monkeys before raxibacumab received FDA approval (Table 2). Initial studies were conducted in rats, and two of these have been published. The first was a randomized, placebo-controlled study in which survival was evaluated at different time intervals after a 24 -hour infusion of anthrax lethal toxin (PA plus lethal factor) ${ }^{32}$ Rats receiving raxibacumab within 6 hours of toxin administration had a better survival rate than those that received raxibacumab at 9 or 12 hours. In the same study, different doses of raxibacumab given 6 hours after toxin infusion were evaluated. The survival rate decreased with lower doses of raxibacumab. In the second study, rats were given a single injection of raxibacumab or placebo 24 hours before administration of the lethal toxin. ${ }^{27}$ The survival rate in rats that received the single raxibacumab dose was $100 \%$, whereas that in rats that received placebo was $0 \%$.

The positive outcomes of the above-mentioned studies led to further evaluation in animal models that better resemble humans. Rabbits are one of the preferred models of inhalational anthrax. In the first study, rabbits were given a single subcutaneous dose of raxibacumab 48 hours before exposure to anthrax spores on day 0 or a single $40 \mathrm{mg} / \mathrm{kg}$ intravenous raxibacumab dose immediately after exposure. ${ }^{29}$ Survival at 14 days was dose-dependent and significantly greater in the raxibacumab group than in the placebo group (which had a survival rate of $0 \%$ ). Bacteremia was noted in all the rabbits that died but not in any of the rabbits given raxibacumab. The second study looked at therapeutic administration of raxibacumab after exposure..$^{29}$ In the first experiment, a $40 \mathrm{mg} / \mathrm{kg}$ intravenous dose of raxibacumab was given at different time intervals starting at time 0 after exposure to anthrax spores. At 14 days post-exposure, all rabbits that had received raxibacumab at 0 and 12 hours were alive, whereas 
Table 2 Animal studies of raxibacumab

\begin{tabular}{|c|c|c|c|c|c|}
\hline Study & Species & Objective & Endpoint & Design & Results \\
\hline \multicolumn{6}{|l|}{ Rat } \\
\hline Cui et a ${ }^{32}$ & $\begin{array}{l}\text { Rat (Sprague- } \\
\text { Dawley) }\end{array}$ & $\begin{array}{l}\text { Post-exposure } \\
\text { prophylaxis }\end{array}$ & $\begin{array}{l}\text { Survival rates } \\
\text { at different } \\
\text { time points }\end{array}$ & $\begin{array}{l}324 \text { rats exposed to } 24 \text {-hour infusion } \\
\text { of anthrax lethal toxin; raxibacumab } \\
\text { was administered at time of, or } 3,6,9 \\
\text { or } 12 \text { hours after initiation of infusion; } \\
\text { raxibacumab given at different } \\
\text { concentrations at } 6 \text { hours }\end{array}$ & $\begin{array}{l}\text { Odds of survival greater for rats } \\
\text { that received raxibacumab early; no } \\
\text { difference from placebo when } \\
\text { received at } 9 \text { and } 12 \text { hours; decrease } \\
\text { in survival with lower concentrations } \\
\text { of raxibacumab given }\end{array}$ \\
\hline Migone et $\mathrm{al}^{27}$ & Rat (Fisher 344) & Pre-exposure & $\begin{array}{l}\text { Survival at } \\
24 \text { hours }\end{array}$ & $\begin{array}{l}30 \text { rats divided into } 6 \text { groups (IV, IM, } \\
\text { or } \mathrm{SC} \text { administration of raxibacumab } \\
\text { or } \lg \mathrm{G} \text { placebo) }\end{array}$ & $\begin{array}{l}100 \% \text { survival rate versus } 0 \% \text { for } \\
\text { all three groups given } \\
\text { raxibacumab, regardless of route } \\
\text { of administration, when compared } \\
\text { with placebo }\end{array}$ \\
\hline
\end{tabular}

\section{Rabbit}

Mazumdar ${ }^{29}$

Rabbit (New

Zealand white)

Pre-exposure and

post-exposure

$\begin{array}{lll}\text { Migone et } \mathrm{al}^{27} & \text { Rabbit (New } & \text { Post-exposure } \\ & \text { Zealand white) } & \text { treatment }\end{array}$ 14-day surviva

72 rabbits divided into 6 groups (placebo or raxibacumab SC at I, 5, 10 , or $20 \mathrm{mg} / \mathrm{kg}$; IV $40 \mathrm{mg} / \mathrm{kg}$ placebo or raxibacumab immediately postexposure) exposed to anthrax spores 14-day survival Time-course experiment: 60 rabbits exposed to anthrax spores, then administered IV raxibacumab at time $0,12,24$, or 36 hours post-exposure; controls given placebo at time 0 . Dose-response experiment: 60 rabbits exposed to anthrax spores and then administered IV raxibacumab 24 hours later $(0,5,10,20$, and $40 \mathrm{mg} / \mathrm{kg})$; another group given raxibacumab $20 \mathrm{mg} / \mathrm{kg} 36$ hours post-exposure 14-day survival 54 rabbits in three equal groups exposed to anthrax spores on day 0 ; if increase in temperature or detection of PA in blood, then given single dose of IV raxibacumab $(20 \mathrm{mg} / \mathrm{kg}$ or $40 \mathrm{mg} / \mathrm{kg}$ ) or placebo

$\begin{array}{lll}\text { Corey et }^{33} & \text { Rabbit (New } & \text { Post-exposure } \\ & \text { Zealand white) } & \begin{array}{l}\text { combined } \\ \text { treatment }\end{array}\end{array}$

Monkey $\begin{aligned} \text { Migone et al }^{27} & \begin{array}{l}\text { Monkey } \\ \text { (Cynomolgus } \\ \text { macaque) }\end{array}\end{aligned}$ Pre-exposure

28-day survival

180 rabbits challenged with anthrax spores and then given intragastric levofloxacin ( $50 \mathrm{mg} / \mathrm{kg}$ daily) or levofloxacin plus IV raxibacumab (40 mg/kg) 84 hours post-exposure
28-day survival 40 monkeys randomized to single SC dose of placebo or raxibacumab (10, 20, or $40 \mathrm{mg} / \mathrm{kg}$ ) 48 hours prior to anthrax spore exposure

28-day survival

40 monkeys randomized to single IV raxibacumab $(20 \mathrm{mg} / \mathrm{kg}$ or $40 \mathrm{mg} / \mathrm{kg})$ or placebo after anthrax spore exposure given upon detection of PA in serum
Higher survival rate in rabbits that received a higher dose Higher survival with earlier
administration; higher survival
at higher doses

Significantly greater survival for both raxibacumab groups than for placebo

24 survivors (65\%) in levofloxacin group and $32(82 \%)$ in levofloxacin plus raxibacumab $(P=0.0874)$

22 monkeys that received raxibacumab survived $(60 \%$ for $10 \mathrm{mg} / \mathrm{kg}, 70 \%$ for $20 \mathrm{mg} / \mathrm{kg}$, and $90 \%$ for $40 \mathrm{mg} / \mathrm{kg}$ ); all monkeys in the placebo group died before day 7

Greater survival for raxibacumab than placebo

Abbreviations: IgG, immunoglobulin; IM, intramuscular; IV, intravenous; SC, subcutaneous; PA, protective antigen.

rabbits that received raxibacumab at 24 and 36 hours had $50 \%$ and $41.7 \%$ survival rates, respectively. In the second experiment, rabbits were exposed to anthrax spores and then given intravenous raxibacumab at different doses. The survival rate at 14 days post-exposure increased in rabbits that received higher doses, with $20 \mathrm{mg} / \mathrm{kg}$ and $40 \mathrm{mg} / \mathrm{kg}$ having the highest survival rates. The third study was an open-label, parallel-group, randomized, placebo-controlled study that randomized rabbits into three groups challenged with anthrax aerosol on day $0 .{ }^{27}$ Upon recording of body 
Table 3 Monoclonal antibodies against PA $^{30}$

\begin{tabular}{llll}
\hline Antibody & Origin & $\begin{array}{l}\text { Binding } \\
\text { epitope }\end{array}$ & Mechanism of action \\
\hline $\begin{array}{llll}\text { Abthrax } \\
\text { AVP-2ID9 }\end{array}$ & IV & Receptor binding inhibition \\
ETI-204 (Anthim ${ }^{\mathrm{TM}}$; Elusys & Human & III & Blocks PA heptamer formation \\
$\begin{array}{l}\text { Therapeutics, Inc., Pine Brook, } \\
\text { NJ, USA) }\end{array}$ & IV & Receptor binding inhibition \\
$\begin{array}{l}\text { MDX I303 (Valortim; } \\
\text { PharmAthene, Inc., }\end{array}$ & Human & III & Disrupts preformed PA heptamers \\
$\begin{array}{l}\text { Annapolis, MD, USA) } \\
\text { IQNPA }\end{array}$ & & \\
WI & Human & IV & Rabbit \\
\hline
\end{tabular}

Abbreviation: PA, protective antigen.

temperature at least $1.1^{\circ} \mathrm{C}$ above baseline or detection of PA in serum, rabbits were given a single dose of raxibacumab (20 mg/kg or $40 \mathrm{mg} / \mathrm{kg}$ ) or placebo. Survival at 14 days was significantly greater in the groups that received raxibacumab ( $28 \%$ for $20 \mathrm{mg} / \mathrm{kg}$ and $44 \%$ for $40 \mathrm{mg} / \mathrm{kg}$ ) when compared with placebo $(0 \%)$. The difference in survival between the two groups that received raxibacumab was not statistically significant. A fourth study evaluated the survival benefit of adding raxibacumab to levofloxacin versus levofloxacin alone 84 hours after inhalational exposure. ${ }^{33}$ Although the difference in survival rate did not reach statistical significance, it was higher in the group that received the combination of levofloxacin and raxibacumab. Half as many deaths occurred in the group that received combination treatment than in the group that received levofloxacin alone.

Monkeys are another preferred model of inhalational anthrax, given their close anatomic and genetic resemblance to humans. The initial study evaluated the efficacy of raxibacumab at different doses using a single subcutaneous injection 48 hours before exposure to spores. ${ }^{27}$ Monkeys that received higher doses had a greater likelihood of survival, the highest being achieved with the $40 \mathrm{mg} / \mathrm{kg}$ dose. Monkeys that survived were rechallenged with anthrax spores one year later, and all were protected. The second study was a single-blind, parallel-group, randomized, placebo-controlled evaluation of the therapeutic efficacy of raxibacumab after exposure to anthrax spores. ${ }^{27}$ Monkeys in this study received a single intravenous dose of raxibacumab $(20 \mathrm{mg} / \mathrm{kg}$ or $40 \mathrm{mg} / \mathrm{kg}$ ) or placebo after detection of PA in serum. The survival rate was higher at 28 days in both raxibacumab groups when compared with placebo.

These animal studies established that raxibacumab is effective against inhalational anthrax, and also demonstrated its effectiveness as a prophylactic agent. There seems to be protection against inhalational rechallenge one year after the initial exposure. Concomitant use with levofloxacin resulted in a clinically meaningful increase in survival 3.5 days after exposure. Raxibacumab adds an additional element of protection against inhalational anthrax not previously covered by antibiotics or vaccination.

\section{Other similar antibodies}

Six other monoclonal antibodies against PA are currently under investigation (Table 3), ${ }^{30}$ and neutralize PA via different mechanisms: inhibition of receptor binding (like raxibacumab); interference with transformation of PA into a heptamer when forming a pore in the cell membrane; and disruption of the preformed PA heptamer by formation of a supercomplex. Other monoclonal antibodies that are currently not in clinical use neutralize PA by interfering with lethal factor and binding or by blocking the enzymatic cleavage of $\mathrm{PA}_{83}$ into $\mathrm{PA}_{63}$ and $\mathrm{PA}_{20}{ }^{30}$ Polyclonal antibodies against PA have also been developed. Human anthrax immunoglobulin (Anthrivig ${ }^{\mathrm{TM}}$, Emergent BioSolutions Inc., Rockville, MD, USA) is derived from the plasma of humans immunized with Anthrax Vaccine Adsorbed vaccine and contains polyclonal antibodies against PA. ${ }^{34}$ Whether these other monoclonal and polyclonal antibodies are as effective as raxibacumab or provide advantages against inhalational anthrax remains to be determined.

\section{Conclusion}

Raxibacumab is a recombinant human monoclonal antibody that neutralizes anthrax toxins by inhibiting binding of PA to cell receptors. It is given intravenously as a single dose and its current FDA-approved indications include use as therapy for and prevention against inhalational anthrax.

To meet the FDA Animal Efficacy Rule requirements, raxibacumab has needed both human and animal studies to evaluate its safety and efficacy, respectively. Animals do not reflect human disease precisely. Therefore, different 
animal models were developed in order to determine survival outcomes and extrapolate these to humans as precisely as possible. Under the current rules, efficacy needs to be demonstrated in at least two different animal species. In addition, post-marketing human efficacy studies are mandated. Meeting these two requirements can be difficult and challenging. In the event of a bioterrorist attack, a post-marketing efficacy study would be a resource-intensive and difficult task to perform given the circumstances. Costly and timely resources have been invested in raxibacumab in order to receive FDA approval.

Current antibiotics or available anthrax vaccines do not provide antitoxin therapy like raxibacumab does. Whether future guidelines should incorporate passive immunity as part of the therapeutic armamentarium against inhalational anthrax needs to be discussed. This is important given the potential for anthrax to be used as a bioterrorist weapon. When combined with currently recommended antianthrax antibiotics, as well as immunization when available, raxibacumab seems to be an effective therapy to combat the deleterious effects of anthrax toxins.

\section{Acknowledgments}

The author would like to thank Dr John T Huggins for reviewing the manuscript and Isabel Bonenfant for assistance in developing the figures.

\section{Disclosure}

The author reports no conflicts of interest in this work.

\section{References}

1. US Food and Drug Administration. FDA approves raxibacumab to treat inhalational anthrax. 2012. Available from: http://www.fda.gov/NewsEvents/Newsroom/PressAnnouncements/ucm332341.htm. Accessed January 10, 2014.

2. US Food and Drug Administration. FDA-approved drug products. 2012. Available from: http://www.accessdata.fda.gov/scripts/cder/drugsatfda/ index.cfm?fuseaction=Search.Label_ApprovalHistory\#labelinfo. Accessed January 10, 2014.

3. US Food and Drug Administration, Department of Health and Human Services. New drug and biological drug products; evidence needed to demonstrate effectiveness of new drugs when human efficacy studies are not ethical or feasible. Final rule. Fed Regist. 2002;67(105): 37988-37998.

4. Meadows M. Project Bioshield: protecting Americans from terrorism. FDA Consum. 2004;38(6):32-33.

5. Russell PK. Project BioShield: what it is, why it is needed, and its accomplishments so far. Clin Infect Dis. 2007;45 Suppl 1:S68-S72.

6. Inglesby TV, O'Toole T, Henderson DA, et al. Anthrax as a biological weapon, 2002: updated recommendations for management. JAMA. 2002;287(17):2236-2252.

7. Wright JG, Quinn CP, Shadomy S, Messonnier N; Centers for Disease Control and Prevention. Use of anthrax vaccine in the United States: recommendations of the Advisory Committee on Immunization Practices (ACIP), 2009. MMWR Recomm Rep. 2010;59(RR-6):1-30.
8. Jernigan JA, Stephens DS, Ashford DA, et al. Bioterrorism-related inhalational anthrax: the first 10 cases reported in the United States. Emerg Infect Dis. 2001;7(6):933-944.

9. Walsh JJ, Pesik N, Quinn CP, et al. A case of naturally acquired inhalation anthrax: clinical care and analyses of anti-protective antigen immunoglobulin G and lethal factor. Clin Infect Dis. 2007;44(7):968-971.

10. Jefferds MD, Laserson K, Fry AM, et al. Adherence to antimicrobial inhalational anthrax prophylaxis among postal workers, Washington, DC, 2001. Emerg Infect Dis. 2002;8(10):1138-1144.

11. Centers for Disease Control and Prevention. Expert panel meetings on prevention and treatment of anthrax in adults. 2014. Available from: http://wwwnc.cdc.gov/eid/article/20/2/13-0687_article.htm. Accessed March 6, 2014.

12. Cote CK, Welkos SL, Bozue J. Key aspects of the molecular and cellular basis of inhalational anthrax. Microbes Infect. 2011;13(14-15): $1146-1155$.

13. Hicks CW, Sweeney DA, Cui X, Li Y, Eichacker PQ. An overview of anthrax infection including the recently identified form of disease in injection drug users. Intensive Care Med. 2012;38(7):1092-1104.

14. Sweeney DA, Hicks CW, Cui X, Li Y, Eichacker PQ. Anthrax infection. Am J Respir Crit Care Med. 2011;184(12):1333-1341.

15. Read TD, Peterson SN, Tourasse N, Baillie LW, Paulsen IT, Nelson KE, et al. The genome sequence of Bacillus anthracis Ames and comparison to closely related bacteria. Nature. 2003;423(6935):81-86.

16. Makino S, Uchida I, Terakado N, Sasakawa C, Yoshikawa M. Molecular characterization and protein analysis of the cap region, which is essential for encapsulation in Bacillus anthracis. J Bacteriol. 1989;171(2): 722-730.

17. Piris-Gimenez A, Corre JP, Jouvion G, Candela T, Khun H, Goossens PL. Encapsulated Bacillus anthracis interacts closely with liver endothelium. J Infect Dis. 2009;200(9):1381-1389.

18. Bradley KA, Mogridge J, Mourez M, Collier RJ, Young JA. Identification of the cellular receptor for anthrax toxin. Nature. 2001;414(6860):225-229.

19. Collier RJ. Membrane translocation by anthrax toxin. Mol Aspects Med. 2009;30(6):413-422.

20. Chitlaru T, Altboum Z, Reuveny S, Shafferman A. Progress and novel strategies in vaccine development and treatment of anthrax. Immunol Rev. 2011;239(1):221-236.

21. Leppla SH. Anthrax toxin edema factor: a bacterial adenylate cyclase that increases cyclic AMP concentrations of eukaryotic cells. Proc Natl Acad Sci U S A. 1982;79(10):3162-3166.

22. Barakat LA, Quentzel HL, Jernigan JA, et al. Fatal inhalational anthrax in a 94-year-old Connecticut woman. JAMA. 2002;287(7): 863-868.

23. Mina B, Dym JP, Kuepper F, et al. Fatal inhalational anthrax with unknown source of exposure in a 61-year-old woman in New York City. JAMA. 2002;287(7):858-862.

24. Agrawal A, Lingappa J, Leppla SH, et al. Impairment of dendritic cells and adaptive immunity by anthrax lethal toxin. Nature. 2003;424(6946): 329-334.

25. Fang H, Xu L, Chen TY, Cyr JM, Frucht DM. Anthrax lethal toxin has direct and potent inhibitory effects on B cell proliferation and immunoglobulin production. J Immunol. 2006;176(10):6155-6161.

26. Bush LM, Abrams BH, Beall A, Johnson CC. Index case of fatal inhalational anthrax due to bioterrorism in the United States. $N$ Engl J Med. 2001;345(22):1607-1610.

27. Migone TS, Subramanian GM, Zhong J, et al. Raxibacumab for the treatment of inhalational anthrax. N Engl J Med. 2009;361(2): 135-144.

28. [No authors listed]. Raxibacumab for anthrax. Med Lett Drugs Ther. 2013;55(1413):27-28.

29. Mazumdar S. Raxibacumab. MAbs. 2009;1(6):531-538.

30. Chen Z, Moayeri M, Purcell R. Monoclonal antibody therapies against anthrax. Toxins (Basel). 2011;3(8):1004-1019.

31. Subramanian GM, Cronin PW, Poley G, et al. A phase 1 study of PAmAb, a fully human monoclonal antibody against Bacillus anthracis protective antigen, in healthy volunteers. Clin Infect Dis. 2005;41(1):12-20. 
32. Cui X, Li Y, Moayeri M, et al. Late treatment with a protective antigen-directed monoclonal antibody improves hemodynamic function and survival in a lethal toxin-infused rat model of anthrax sepsis. $J$ Infect Dis. 2005;191(3):422-434.

33. Corey A, Migone TS, Bolmer S, et al. Bacillus anthracis protective antigen kinetics in inhalation spore-challenged untreated or levofloxacin/raxibacumab-treated New Zealand white rabbits. Toxins (Basel). 2013;5(1):120-138
34. Mytle N, Hopkins RJ, Malkevich NV, et al. Evaluation of intravenous anthrax immune globulin for treatment of inhalation anthrax. Antimicrob Agents Chemother. 2013;57(11):5684-5692.

\section{Publish your work in this journal}

Infection and Drug Resistance is an international, peer-reviewed openaccess journal that focuses on the optimal treatment of infection (bacterial, fungal and viral) and the development and institution of preventive strategies to minimize the development and spread of resistance. The journal is specifically concerned with the epidemiology of antibiotic
Dovepress

resistance and the mechanisms of resistance development and diffusion in both hospitals and the community. The manuscript management system is completely online and includes a very quick and fair peerreview system, which is all easy to use. Visit http://www.dovepress.com/ testimonials.php to read real quotes from published authors.

Submit your manuscript here: http://www.dovepress.com/infection-and-drug-resistance-journal 